\title{
Pengalihan Hak Atas Tanah Yang Objeknya Diikat Hak Tanggungan
}

\author{
Anak Agung Sagung Istri Karina Prabasari ${ }^{1}$, I Nyoman Sirtha ${ }^{2}$ \\ ${ }^{1}$ Fakultas Hukum Universitas Udayana, E-mail: karinaprabasari20@gmail.com \\ ${ }^{2}$ Fakultas Hukum Universitas Udayana, E-mail: nyoman_sirtha@unud.ac.id
}

\begin{abstract}
Info Artikel
Masuk : 12 Januari 2021

Diterima : 08 Februari 2021

Terbit : 01 April 2021

Keywords :

Mortgage, transfer, Mortgage

object

Kata kunci:

Hak Tanggungan, pengalihan, objek Hak Tanggungan

Corresponding Author:

Anak Agung Sagung Istri

Karina Prabasari,

E-mail:

karinaprabasari20@gmail.co

$\mathrm{m}$

DOI :

10.24843/AC.2021.v06.i01.p11
\end{abstract}

\begin{abstract}
The purpose of this paper is to find out and analyze whether or not it is permissible to transfer HT objects and about the type of agreement used to transfer some HT objects. The writing method used in this research is empirical legal research method with qualitative analysis, with a sociological juridical approach. The data sources used consisted of primary data through interviews with several Notaries / PPAT and secondary data including laws and regulations, books and journals. The results showed, first, that the transfer of HT objects is allowed even though it was not previously agreed in the APHT. Second, the types of agreements used consist of the agreement to carry out the sale and purchase of some HT objects in the form of PPJB and subsequently AJB, agreements related to the purchase and sale of HT objects, agreements related to the process of breaking and separating $H T$ objects, making SKMHT and APHT .
\end{abstract}




\section{Pendahuluan}

Perjanjian kredit merupakan bentuk kesepakatan yang dibuat oleh pemberi dan penerima kredit. Menurut Pasal 1 ayat (12) Undang-Undang No. 10 Th. 1998 tentang Perbankan (selanjutnya disingkat UU Perbankan) menentukan, bahwa :

"Kredit adalah penyediaan uang atau tagihan yang dapat dipersamakan dengan itu, berdasarkan persetujuan atau kesepakatan pinjam-meminjam antara bank dengan pihak lain yang mewajibkan pihak peminjam untuk melunasi hutangnya setelah jangka waktu tertentu dengan jumlah bunga, imbalan atau pembagian hasil keuntungan."

Pada perjanjian kredit, segala hak dan kewajiban antara kreditur dan debitur dicantumkan, baik itu mengenai kewajiban kreditur untuk segera mencairkan kredit apabila akad kredit telah dilangsungkan dan hak kreditur untuk menagih angsuran serta mengeksekusi benda jaminan apabila terjadi wanprestasi, maupun mengenai hak debitur untuk mencairkan dana kredit serta kewajiban debitur untuk membayar angsuran kredit tepat pada waktunya serta kewajiban- kewajiban lainnya yang terkait dengan syarat- syarat kredit nantinya akan dicantumkan secara terperinci dalam akta perjanjian kreditnya. Akta perjanjian kredit inilah yang nantinya akan dijadikan alat bukti dikemudian hari apabila debitur tidak memenuhi prestasinya sebagaimana apa yang dijanjikan dalam perjanjian kredit yang telah disepakati bersama. ${ }^{1}$

Perjanjian kredit yang merupakan bentuk kesepakatan antara debitur/penerima kredit dengan kreditur/pemberi kredit yang diberikan oleh lembaga perbankan memiliki fungsi, yaitu sebagai berikut: ${ }^{2}$

(1) sebagai perjanjian pokok, artinya perjanjian kredit merupakan sesuatu yang menentukan batal atau tidaknya perjanjian lain yang mengikatnya;

(2) sebagai alat bukti, batasan hak dan kewajiban antara debitur dan kreditur;

(3) sebagai alat untuk melakukan monitoring kredit."

Berkaitan dengan kredit, lembaga jaminan berperan penting dalam menjamin kelangsungan kegiatan usaha tersebut. Salah satunya adalah penanggulangan resiko terhadap kredit yang diberikan oleh bank. ${ }^{3}$ Tujuan adanya jaminan kredit, diantaranya: Pengamanan pelunasan kredit, mendorong motivasi untuk pelunasan hutang, dan fungsi lain menyangkut pelaksanaan perbankan. Berdasarkan Pasal 8 ayat (1) UU Perbankan menegaskan bahwa,

Dalam memberikan kredit atau pembiayaan berdasarkan Prinsip Syariah, Bank Umum wajib mempunyai keyakinan berdasarkan analisis yang mendalam atas itikad dan kemampuan serta kesanggupan Nasabah Debitur untuk melunasi utangnya atau mengembalikan pembiayaan dimaksud sesuai dengan yang diperjanjikan.

1 Utami, P. D. Y., Diantha, I. M. P., \& Sarjana, I. M. (2018). Kedudukan Hukum Grosse Akta Pengakuan Hutang Notariil dalam Pemberian Kredit Perbankan. Acta Comitas: Jurnal Hukum Kenotariatan, 3(1), 201-214. h.203.

2 Haryati, S.(2009). Pertumbuhan kredit perbankan di Indonesia: Intermediasi dan pengaruh variabel makro ekonomi. Jurnal Keuangan dan Perbankan, 13(2), 299-310, h.305.

3 Imaniyanti, Neni Sri. (2010). Pengantar Hukum Perbankan Indonesia. Bandung: PT. Refika Aditama. h. 151 
Jaminan kebendaan selalu mengikuti bendanya dimanapun benda tersebut berada, dan memberikan sifat preferent. Misalnya Hak Tanggungan, Jaminan Fidusi, Gadai dan Hipotek Kapal Laut. Sedangkan jaminan perorangan hanya menimbulkan kewajiban bagi pihak- pihak tertentu saja. Selain istilah jaminan, didalam UU Perbankan, dikenal adanya istilah agunan. Agunan adalah suatu jaminan tambahan yang diserahkan oleh Debitur kepada bank dalam rangka pemberian kredit atau pembiayaan berdasarkan Prinsip Syariah. Salah satu jenis agunan yang paling sering diterima oleh bank dalam pemberian kredit adalah agunan dalam bentuk hak atas tanah. ${ }^{4}$

Tanah merupakan jaminan yang dianggap dapat memberikan rasa aman dan dianggap paling efektif oleh lembaga perbankan. Bukan hanya memiliki harga tinggi, nilai tanah tidak mengalami kemerosotan dan terus meningkat. Hal ini menunjukan bahwa tanah berperan penting dalam perekonomian dan kehidupan masyarakat Indonesia. Tanah yang dapat dipergunakan sebagai penjaminanan kredit oleh pihak bank harus dilakukan pengikatan HT, sebagaimana disebutkan dalam penjelasan Undang-Undang Nomor 4 Tahun 1996 tentang Hak Tanggungan (selanjutnya disingkat UUHT) pada angka 5 alinea ke 3 berbunyi: "...Hak Tanggungan merupakan satu-satunya lembaga hak jaminan atas tanah..." Selanjutnya menurut Pasal 1 ayat (1), UUHT dijelaskan bahwa :

Hak Tanggungan adalah Hak Jaminan yang dibebankan pada hak atas tanah sebagaimana yang dimaksud dalam Undang-Undang Nomor 5 Tahun 1960 tentang Peraturan Dasar Pokok-Pokok Agraria, berikut atau tidak berikut bendabenda lain yang merupakan satu kesatuan dengan tanah itu, untuk pelunasan utang tertentu, yang memberikan kedudukan yang diutamakan kepada kreditor tertentu terhadap kreditor-ktreditor lain.

Adapun objek HT yang pengaturannya terdapat pada Pasal 4 ayat (1) UUHT, bahwa "Hak atas tanah yang dapat dibebani Hak Tanggungan, antara lain: (a) Hak Milik; (b) Hak Guna Usaha; (c) Hak Guna Bangunan." Selanjutnya pada ayat (2) "Selain hak-hak atas tanah sebagaimana dimaksud pada ayat (1), Hak Pakai atas tanah Negara yang menurut ketentuan yang berlaku wajib didaftar dan menurut sifatnya dapat dipindahtangankan dapat juga dibebani." Lembaga keuangan pemberi fasilitas kredit lebih menyukai tanah sebagai jaminan untuk pembayaran utang. ${ }^{5} \mathrm{Hal}$ ini dikarenakan tanah adalah objek jaminan yang mudah dipindahtangankan melalui jual beli dan sifatnya yang dapat memberikan hak istimewa kepada kreditur apabila objek tersebut diikat dengan Hak Tanggungan. ${ }^{6}$ Adapun syarat tanah dapat dibebankan Hak Tanggungan adalah, bahwa tanah yang menjadi jaminan tersebut benar-benar Hak Milik pemberi Hak Tanggungan yang yang ditegaskan dalam Akta Pemberian Hak Tanggungan (APHT) yang bersangkutan ${ }^{7}$.

${ }^{4}$ Utami, P.D.Y. (2019). Kajian Yuridis Agunan Yang Diambil Alih (AYDA) Oleh Bank. Kerta Dyatmika, 16(2), 69-77. h.70

5 Djatmiko, A.A. (2017). Aktualisasi Prinsip 5C Pada Pelaksanaan Perjanjian Kredit Dengan Jaminan Hak Atas Tanah Belum Bersertifikat Jurnal Yustitiabele, 3(1), 129-157, h. 131.

${ }^{6}$ Perangin, Effendi, (1995). Praktek Penggunaan Tanah Sebagai Jaminan Kredit. Jakarta: PT Raja Grafindo Persada. h 9.

7 Salim HS. (2004). Perkembangan Hukum Jaminan di Indonesia. Jakarta: PT Raja Grafindo Persada. h.105. 
Adanya pembebanan Hak Tanggungan terhadap tanah yang dijaminkan akan memberikan perlindungan hukum kepada Bank/kreditur sebagai pihak yang paling rentan setelah adanya pencairan kredit, hal ini dikarenakan pembebanan HT atas objek jaminan, membuat pemberi jaminan tidak dapat melakukan apapun atas obyek jaminan, bahkan menghapus hak pemberi jaminan atas obyek jaminan apabila debitur wanprestasi. Adapun menurut Widayati, "untuk menghapus Hak tanggungan atas tanah yang menjadi objek jaminan dan menjadikan pemilik tanah memiliki kekuasaan atas tanah jaminan kembali, maka harus dilakukan pemenuhan prestasi melalui pembayaran seluruh hutang berikut bunga, atau eksekusi atas obyek hak tanggungan." ${ }^{8}$

Keuntungan yang didapatkan Bank/kreditur dengan membebankan HT pada objek jaminan, adalah pertama, Bank memiliki hak istimewa untuk diutamakan atau didahului terkait pelunasan hutang(droit de preference). Kedua, sifat HT yang mengikuti dimanapun obyek HT itu berada(droit de suit). Ketiga, memenuhi asas spesialitas dan asas publisitas sehingga dapat memberikan kepastian yang jelas terhadap pihak ketiga. Keempat mudah untuk dilakukan eksekusi ketika terjadi wanprestasi tanpa harus menunggu putusan pengadilan. ${ }^{9}$ Asas publisitas adalah asas yang menyatakan bahwa tanah yang menjadi objek HT wajib didaftarkan pada kantor pertanahan. Asas spesialitas adalah asas yang berkaitan dengan uraian yang jelas dan terperinci mengenai obyek Hak HT yang meliputi rincian mengenai sertifikat hak atas tanah, sebagaimana ketentuan Pasal 11 ayat (1) huruf (e) yang menentukan "Di dalam Akta Pemberian Hak Tanggungan wajib dicantumkan uraian yang jelas mengenai obyek Hak Tanggungan. Uraian yang jelas mengenai obyek Hak Tanggungan adalah uraian mengenai sertifikat hak atas tanah seperti disebutkan diatas".

Selain asas tersebut diatas terdapat asas lain juga, salah satunya asas tidak bisa dibagibagi. Menurut Pasal 2 ayat (1) UUHT "Hak Tanggungan mempunyai sifat tidak dapat dibagi-bagi, kecuali jika diperjanjikan dalam Akta Pemberian Hak Tanggungan." Asas ini memiliki maksud bahwa sebagian obyek hak tanggungan tidak menjadi hapus walaupun sebagaian hutangnya dilunasi dari beban HT, melainkan seluruh obyek HT tertap terbebani HT untuk sisa hutang yang belum dilunasi. Namun hal ini disimpangi sebagaimana diatur dalam Pasal 2 ayat (2) UUHT yang berbunyi:

"Apabila Hak Tanggungan dibebankan pada beberapa hak atas tanah, dapat diperjanjikan dalam Akta Pemberian Hak Tanggungan yang bersangkutan, bahwa pelunasan utang yang dijamin dapat dilakukan dengan cara angsuran yang besarnya sama dengan nilai masing-masing hak atas tanah yang merupakan bagian dari obyek Hak Tanggungan, yang akan dibebaskan dari Hak Tanggungan tersebut, sehingga kemudian Hak Tanggungan itu hanya membebani sisa obyek Hak Tanggungan untuk menjamin sisa utang yang belum dilunasi."

${ }^{8}$ Widayati, R., \& Herman, U. (2019). Penyelesaian Kredit Bermasalah Pada PT. Bank Perkreditan Rakyat (BPR) Nagari Kasang. Makalah. h.4

9 Wiguna, M.O.C. (2018). Surat Kuasa Membebankan Hak Tanggungan Dan Pengaruhnya Terhadap Pemenuhan Asas Publisitas Dalam Proses Pemberian Hak Tanggungan. Jurnal Legislasi Indonesia, 14(4), 439-446, h.430. 
Tujuan adanya penyimpangan terhadap asas tidak dapat dibagi-bagi tersebut di atas adalah untuk memfasilitasi developer yang membutuhkan tambahan dana pada pembangunan kompleks perumahan. Untuk mendapatkan fasilitas kredit, maka Developer memberikan bidang tanah kompleks perumahan sebagai jaminan fasilitas kredit yang akan dibebankan dengan hak tanggungan. Sehingga berdasarkan ketentuan Pasal 2 ayat (2) UUHT, developer boleh menjual sebagian bangunan dan tanah yang dibebani HT kepada pihak ketiga. Adanya penyimpangan asas tidak dapat dibagi-bagi tersebut oleh UUHT bukannya tidak akan menimbulkan masalah. Memindahtangankan sebagian objek jaminan Hak Tanggungan tentunya dapat menimbulkan permasalahan baru, yaitu disaat debitur pemberi hak tanggungan wanprestasi, namun hal tersebut dapat diselesaikan dengan cara: melakukan eksekusi atas obyek Hak Tangungan dengan cara lelang, atau pemberi Hak Tanggungan mengalihkan obyek hak tanggungan kepada debitur baru melalui jual beli. Ketiga, debitur mengalihkan sebagian dari tanah obyek HT dengan jual beli untuk membayar kredit tersisa. ${ }^{10}$

Tindakan yang diambil untuk penyelesaian kredit telah sesuai dengan aturan, hanya saja pada penyelesaian dengan cara ketiga ini, ternyata tidak sesuai dengan salah satu asas HT, yaitu asas tidak dapat dibagi-bagi. Menurut apa yang diuraikan diatas terkait pengalihan objek HT, maka terdapat dua rumusan masalah atas penelitian ini, yaitu apakah diperbolehkan sebagian obyek hak tanggungan dipindah-tangankan? Serta apa saja jenis-jenis perjanjian yang dipakai untuk mengalihkan sebagian objek Hak Tanggungan?

Adapun tujuan dari penelitian ini ada dua, yaitu pertama, untuk mengetahui dan menganalisis mengenai diperbolehkan atau tidaknya pemindahtanganan objek Hak Tanggungan. Kedua, untuk mengetahui dan menganalisis mengenai jenis-jenis perjanjian yang digunakan untuk mengalihkan sebagian objek Hak Tanggungan tersebut.

Terdapat penelitian terdahulu yang memiliki kemiripan dengan penelitian ini, yaitu antara lain :

1. Jurnal berjudul "Perlindungan Hukum Bagi Kreditor Pemegang HAk Tanggungan Atas Pemberian Kredit Dengan Jaminan Hak Guna Bangunan Terhadap Debitor Yang Wanprestasi" oleh Evani Rahayu, Nyoman Nurjaya, dan Bambang Winarno dari Universitas Brawijaya pada tahun 2014 yang meneliti "mengenai pemenuhan prinsip kehati-hatian Bank dalam perjanjian oleh pihak Bank selaku Kreditor terhadap pemberian kredit dengan jaminan Hak Guna Bangunan serta untuk menganalisis dan mendeskripsikan mengenai perlindungan hukum bagi Kreditor pemegang Hak Tanggungan atas pemberian kredit dengan jaminan Hak Guna Bangunan terhadap Debitor yang wanprestasi serta jangka waktu Hak Guna Bangunanya berakhir. Kesimpulan yang didapatkan adalah untuk menjamin adanya perlindungan hukum bagi Kreditor pemegang Hak Tangungan yang dibebankan pada Hak Guna Bangunan perlu melakukan upaya-upaya hukum untuk melindungi kepentingannya agar tetap memiliki kedudukan preferent

10 Sari, A. A. I. W., Atmadja, I. B. P., \& Darmadi, A. A. S. W. (2015). Pelaksanaan Perjanjian Kredit Jaminan Perorangan Terkait Debitur Wanprestasi Pada Bank Perkreditan Rakyat. Kertha Semaya: Journal Ilmu Hukum, 1-15, h.4. 
terhadap jaminan tersebut sehingga dapat mengeksekusi obyek jaminan dan memiliki kedudukan yang diutamakan dari Kreditor lain, maka pada saat penandatanganan APHT haruslah dicantumkan klausula kuasa agar Kreditor dapat mengurus perpanjangan haknya jika nantinya jangka waktu Hak Guna Bangunannya akan berakhir." ${ }^{11}$

2. Jurnal berjudul "Peningkatan Hak Guna Bangunan Rumah Tinggal Dibebani Hak Tanggungan Menjadi Hak Milik Diatas Hak Pengelolaan" oleh Aflinda Dewi dari Universitas Andalas pada tahun 2019 yang meneliti "mengenai peningkatan HGB untuk rumah tinggal yang dibebani HT menjadi hak milik, dan proses pembebanan HT atas HGB yang telah berubah menjadi Hak Milik. Kesimpulan yang didapatkan bahwa HGB Rumah Tinggal yang dibebani Hak Tanggungan dapat dimohonkan Peningkatan Hak milik oleh Debitur, tanpa melunasi hutangnya terlebih dahulu pada kreditur dan Pembebanan HT atas Hak Milik hasil perubahan dibuat dihadapan PPAT oleh Kreditur berdasarkan SKMHT yang diberikan oleh Debitur kepada Kreditur sebelum Peningkatan Hak milik, dan selambat-lambatnya 7 (tujuh) hari setelah pemberian HT harus dikirim oleh PPAT melalui petugasnya ke kantor Pertanahan setempat." ${ }^{12}$

Kedua tulisan tersebut memiliki pokok permasalahan yang berbeda dengan tulisan ini, dimana tulisan ini memfokuskan pada boleh atau tidaknya obyek hak tanggungan dipindahtangankan, serta jenis-jenis perjanjian yang dipakai untuk mengalihkan sebagian objek Hak Tanggungan.

\section{Metode Penelitian}

Metode penelitian ini memuat jenis penelitian empiris atau penelitian lapangan, dan pendekatan yang digunakan adalah pendekatan yuridis sosiologis dengan cara mengkonsepsikan hukum sebagai institusi sosial yang riil dalam sistem kehidupan nyata. ${ }^{13}$ Sumber data yang digunakan terdiri data primer dan data sekunder. Tehnik pengumpulan data, untuk data primer diperoleh langsung dari sumber utama di lapangan yaitu melalui tehnik wawancara dan untuk data sekunder diperoleh dari tehnik kepustakaan, dalam hal ini terdiri dari undang-undang, buku-buku dan artikelartikel. Tehnik pengambilan sample dengan Purposive sampling atau judgmental sampling, yaitu penarikan sample yang dilakukan dengan memilih subjek berdasarkan kriteria spesifik yang dietapkan peneliti. Selanjutnya Data yang diperoleh kemudian dilakukan analisi dengan menggunakan analisis kualitatif, yaitu dengan menyusun secara sistematis dan logis setiap data yang didapatkan untuk memperoleh jawaban atas permasalahan yang diteliti.

11 Rahayu, E. (2014). Perlindungan Hukum Bagi Kreditor Pemegang Hak Tanggungan Atas Pemberian Kredit dengan Jaminan Hak Guna Bangunan terhadap Debitor yang Wanprestasi. Kumpulan Jurnal Mahasiswa Fakultas Hukum,1(1).

12 Dewi, A. (2019). Peningkatan Hak Guna Bangunan Rumah Tinggal Dibebani Hak Tanggungan Menjadi Hak Milik Diatas Hak Pengelolaan. JCH (Jurnal Cendekia Hukum), 5(1), 18-31.

${ }^{13}$ Efendi, Junaidi \& Johnny Ibrahim. (2016). Metode Penelitian Hukum Normatif dan Empiris. Jakarta: Prenadamedia Group.h.153 


\section{Hasil Dan Pembahasan}

\subsection{Pemindahtanganan Objek Jaminan Hak Tangungan}

Pasal 2 ayat (1) UUHT mengatur mengenai pemindahtanganan sebagian objek Hak Tanggungan, yaitu menentukan bahwa: "Hak Tanggungan mempunyai sifat tidak dapat dibagi-bagi, kecuali jika diperjanjikan dalam Akta Pemberian Hak Tanggungan sebagaimana dimaksud pada ayat (2)." Berdasarkan isi pasal tersebut maka dimungkinkan dilakukan pengalihan sebagian objek Hak Tanggungan, asal sebelumnya diperjanjikan dalam APHT. Berdasarkan hasil wawancara dengan Notaris Sri Andayani SH., Notaris/PPAT Denpasar, bahwa jika dalam APHT tidak memperjanjikan adanya pengalihan objek HT, maka tanah yang menjadi obyek hak tanggungan tidak dapat dilakukan jual beli walaupun hanya untuk sebagian tanah, karena itu para pihak harus menyepakati sebelum dilakukannya pembebanan HT. Hal ini dilakukan untuk mempermudah para pihak jika harus dilakukan pengalihan sebagian objek HT. ${ }^{14}$

Sependapat dengan pernyataan Notaris Sri Andayani SH, Notaris Mahayani SH., juga mengatakan bahwa sebagian obyek HT tidak dapat dialihkan jika dalam HT tidak diatur/diperjanjikan. ${ }^{15}$ Sedangkan menurut Notaris I Wayan Sugitha SH, untuk melakukan pengalihan sebagian objek HT, maka harus dilihat dulu jenis tanah dari obyek HT tersebut. Jika jenis tanah tersebut diperuntukkan untuk perumahan, maka penjualan atas sebagian obyek HT dapat dilaksanakan, namun jika tanah tersebut tidak diperuntukkan untuk perumahan, maka hal tersebut tidak dapat dilakukan. Hal ini juga berlaku untuk tanah persawahan karena tanah persawahan tidak bisa dilakukan pemecahan atau pemisahan jika luasnya kurang dari dua hektar. ${ }^{16}$

Notaris I Wayan Sugitha SH., berpendapat bahwa, penjualan sebagian tanah yang menjadi objek HT sebenarnya dimungkinkan, bahkan dalam APHT pun terdapat klausula yang memperbolehkan hal tersebut. ${ }^{17}$ Sebagaimana hal ini diatur dalam Pasal 2 ayat (2) UUHT yang menentukan bahwa:

"Dalam hal Obyek Hak Tanggungan kemudian dipecah sehingga Hak Tanggungan membebani beberapa hak atas tanah, Debitor dapat melakukan pelunasan utang yang dijamin dengan Hak Tanggungan dengan cara angsuran yang besarnya sama dengan nilai masing-masing hak atas tanah tersebut, yang dibebaskan dari Hak Tanggungan, sehingga kemudian Hak Tanggungan itu hanya membebani sisa Obyek Hak Tanggungan untuk menjamin sisa utang yang belum dilunasi. Nilai masing-masing hak atas tanah tersebut akan ditentukan berdasarkan kesepakatan antara Pihak Pertama dengan Pihak Kedua."

\footnotetext{
${ }^{14}$ Hasil wawancara dengan Notaris Sri Andayani SH., Notaris/PPAT Denpasar pada tanggal tanggal 9 Oktober 2020

${ }^{15}$ Hasil wawancara Notaris Mahayani SH., Notaris/PPAT Badung dari hasil wawancara pada tanggal 9 Oktober 2020

16 Hasil wawancara Notaris I Wayan Sugitha, SH., Notaris/PPAT Denpasar dari hasil wawancara pada tanggal 10 Oktober 2020

17 Ibid.
} 
Pada awalnya Badan Pertanahan Nasional (BPN) tidak memperbolehkan pengalihan sebagian obyek HT. Alasan tersebut sama dengan alasan yang sampaikan oleh Notaris Sri Andayani SH., namun kemudian BPN mengijinkan untuk melakukan pengalihan objek HT dengan dasar Pasal 2 ayat (2) UUHT dan sifat Hak Tanggungan yaitu droit de suite, sebagaimana diatur pada Pasal 7 UUHT yang menentukan bahwa "hak tanggungan tetap mengikuti obyeknya dalam tangan siapa pun obyek tersebut berada." Berdasarkan pasal ini, menunjukkan bahwa obyek hak tanggungan dapat dipindahtangankan kepada pihak lain. ${ }^{18}$

Pada perjanjian, kepentingan para pihak adalah hal utama dari kesepakatan. Hal ini guna mengakomodasi kepentingan masing-masing pihak. Untuk itu penulis sependapat dengan Notaris I Wayan Sugitha SH., bahwa sebagian obyek hak HT dapat dialihkan, walaupun tidak diatur dalam APHT sebelumnya. Fungsi UUHT adalah sebagai pengatur (aanvullendrecht) yang sifatnya tidak memaksa. UUHT hanya mengikat jika dan sepanjang para pihak tidak menentukan peraturan yang lain dengan perjanjian. UUHT hanya bermaksud mengisi kekosongan hukum yang dibuat oleh para pihak.

Untuk menjual sebagian obyek HT yang tidak dibuat perjanjian sebelumnya dalam APHT, jika disepakti oleh para pihak, maka harus dibuatkan pernyataan secara tertulis untuk menghapuskan seluruh obyek HT dari beban HT terlebih dahulu oleh pemegang HT. Pernyataan itu kemudian menjadi dasar bagi BPN untuk melakukan roya HT. Setelah dilakukan roya HT, dibuat SKMHT untuk menjamin kreditur. Berikutnya, setelah sebagian objek HT sebagaimana yang telah disepakati bersama antara pihak kreditur, debitur dan pembeli, dilakukanlah pemecahan atau pemisahan, maka objek HT dapat dijual kepada pembeli, sedangkan untuk tanah yang sebagian lagi akan dibebani lagi dengan hak tanggungan dan dibuatkan APHT. Sebenarnya pembuatan SKMHT dalam hal ini tidak cukup kuat untuk melindungi kreditur. Dikhawatirkan muncul kreditur lain setelah dilakukan roya HT atas seluruh tanah obyek HT. ${ }^{19}$ Notaris Sri Andayani SH, juga menyatakan bahwa langkah ini tidak mungkin dilaksanakan dalam praktek karena sangat merugikan kreditur karena setelah dilakukan roya, kedudukan kreditur sebagai pemegang HT sangat lemah. ${ }^{20}$

Menjual beberapa bagian objek HT hanya dimungkinkan jika hasil jual beli tersebut dapat menutupi seluruh hutang. Karena itu tidak ada jalan yang dapat dilakukan untuk menjual sebagian obyek HT dengan tujuan menutup sebagian hutang. ${ }^{21}$ Jika jual beli sebagian obyek HT tersebut digunakan untuk menutup keseluruhan hutang maka jalan yang dapat dilakukan adalah dengan membuat pengikatan jual beli antara pembeli dengan pemberi HT/debitur dengan sepengetahuan/persetujuan dari

${ }^{18}$ Ibid.

${ }^{19}$ Doly, D. (2016). Aspek Hukum Hak Tanggungan Dalam Pelaksanaan Roya. Negara Hukum: Membangun Hukum untuk Keadilan dan Kesejahteraan,2(1), 103-128.h.112.

${ }^{20}$ Hasil wawancara dengan Notaris Sri Andayani SH., Notaris/PPAT Denpasar pada tanggal tanggal 9 Oktober 2020.

${ }^{21}$ Dewi, A. (2019). Peningkatan Hak Guna Bangunan Rumah Tinggal Yang Dibebani Hak Tanggungan Menjadi Hak Milik Diatas Hak Pengelolaan. JCH (Jurnal Cendekia Hukum), 5(1), 18-31.h.23. 
pemegang HT/kreditur dan uang yang didapatkan tesebut dipakai untuk melunasi hutang pemberi HT/debitur kepada pemegang HT/kreditur.

Kenyataannya sesuai praktek di lapangan, pemegang HT/kreditur berkeberatan karena pemegang HT/kreditur lebih menyukai jika nilai jaminan lebih tinggi dari piutang yang diberikan. Hal ini dikarenakan tidak ada satupun perjanjian yang dapat memberikan perlindungan kepada pemegang HT/kreditur, SKMHT ataupun APHTpun tidak akan mampu memberikan perlindungan sebagai kreditur preferent bila belum didaftarkan ke BPN, karena kedudukan sebagai kreditur preferent baru akan lahir pada hari ke tujuh setelah warkah diterima secara lengkap oleh BPN. ${ }^{22}$ Sehingga pengalihan sebagian objek HT sebenarnya terlalu beresiko, terutama ketika telah dilakukan roya dan muncul kreditur lain, untuk itu tidak ada satupun perjanjian yang bisa digunakan sebagai dasar hukum dalam pengalihan obyek hak tanggungan.

Terkait hal tersebut, Notaris Wayan Sugitha, SH., mengatakan terdapat beberapa langkah-langkah yang masih memungkinkan untuk dilakukan dalam menjual sebagian objek HT, yaitu sebagai berikut: ${ }^{23}$

(1) dibuat perjanjian penanggungan atau borghtoch, perjanjian ini dibuat untuk menjamin kedudukan kreditur yang lemah;

(2) roya atas seluruh tanah obyek hak tanggungan;

(3) dilakukan pemecahan atau pemisahan atas bidang tanah yang disepakati para pihak;

(4) proses jual beli dan balik nama atas tanah hasil pemisahan atau pemecahan kepada pembeli dan uang hasil penjualan digunakan untuk membayar angsuran debitur kepada kreditur;

(5) Dibuat APHT baru peringkat pertama.

Menurut penulis, dilakukan roya atas seluruh obyek HT sangat penting, menurut pendapat Kartini Muljadi dan Gunawan Widjaja, akibat dari bidang tanah dipisah, dengan dipisah di sini, dimaksudkan dilahirkan hak atas tanah baru di samping hak atas tanah sebelumnya yang telah ada. Status tanah yang baru sama dengan status hak atas tanah sebelum pemisahan dilakukan; Dipecah, berbeda dari pemisahan, pemecahan melahirkan hak atas tanah baru secara keseluruhan, dengan hapusnya hak atas tanah sebelumnya. Status dari seluruh hak atas tanah yang baru ini adalah sama dengan status hak atas tanah sebelum pemecahan dilakukan, yang selanjutnya hapus demi hukum tersebut. 24

Berdasarkan pendapat tersebut diatas, maka cara yang dapat ditempuh dalam pengalihan sebagian objek HT adalah melakukan pemisahan hak atas tanah terlebih dahulu, walaupun hal tersebut dapat mengakibatkan luas tanah dalam sertifikat

22 Siswanto, C. T. (2016). Pembebanan Hak Tanggungan Yang Didahului Surat Kuasa Membebankan Hak Tanggungan (SKMHT) Di Kantor Pertanahan Kabupaten. Kota Di Wilayah Daerah Istimewa Yogyakarta. Jurnal Cakrawala Hukum, 12(1), h.35.

23 Hasil wawancara Notaris I Wayan Sugitha, SH., Notaris/PPAT Denpasar dari hasil wawancara pada tanggal 10 Oktober 2020

24 Muljadi, Kartini dan Gunawan Widjaja. (2005). Seri Hukum Harta Kekayaan: Hak Tanggungan. Jakarta: Prenada Media Group. h. 213. 
menjadi berkurang. ${ }^{25}$ Tanah hasil pemecahan dan menimbulkan status hukum yang sama dengan status hukum bidang tanah semula. Biarpun status hukumnya sama, kalau satuan-satuan bidang tanah hasil pemecahan itu masing-masing diberi nomor baru, menurut hukum masing-masing merupakan hak baru, bukan pecahan dari hak yang lama. Akibat dengan diberikannya nomor baru adalah hak yang semula menjadi hapus. Dengan hapusnya hak tersebut, menjadi hapus juga karena hukum hak tanggungan dan beban-beban lain yang membebaninya. ${ }^{26}$

Adapun langkah-langkah yang ditempuh untuk mengalihkan sebagian objek HT berdasarkan Peraturan Pemerintah Nomor 24 Tahun 1997 tentang Pendaftaran Tanah (selanjutnya disingkat PP No. 24 Th. 1997) adalah dengan dilakukan pemecahan dan pemisahan. Menurut PP No. 24 Th. 1997 Pasal 48 ayat (1) menentukan, bahwa "Atas permintaan pemegang hak yang bersangkutan, satu bidang tanah yang sudah didaftar dapat dipecah secara sempurna menjadi beberapa bagian, yang masing-masing merupakan satuan bidang baru dengan status hukum yang sama dengan bidang tanah semula." Selanjutnya pada ayat (3) menentukan, bahwa

"Jika hak atas tanah yang bersangkutan dibebani hak tanggungan, dan atau beban-beban lain yang terdaftar, pemecahan sebagimana dimaksud pada ayat (1) baru boleh dilaksanakan setelah diperoleh persetujuan tertulis dari pemegang hak tanggungan atau pihak lain yang berwenang menyetujui penghapusan beban yang bersangkutan."

Pengaturan pengalihan sebagian objek HT juga diatur pada dan Peraturan Menteri Agraria/ Kepala Badan Pertanahan Nasional No. 3 Th. 1997 tentang Ketentuan Pelaksanaan Peraturan Pemerintah Nomor 24 Tahun 1997 (selanjutnya disingkat Permen No. 3 Th. 1997), yaitu pada Pasal 124 yang menentukan, bahwa :

Ayat (1) "Pendaftaran hapusnya Hak Tanggungan atas sebagian obyek Hak Tanggungan dapat dilakukan berdasarkan pelunasan sebagian utang yang dijamin, dengan ketentuan bahwa: (1) obyek Hak Tanggungan terdiri dari beberapa hak, dan (2) kemungkinan hapusnya sebagian Hak Tanggungan karena pelunasan sebagian utang tersebut diperjanjikan di dalam Akta Pemberian Hak Tanggungan."

Ayat (2) "Pendaftaran hapusnya Hak Tanggungan atas sebagian obyek Hak Tanggungan juga dapat dilakukan walaupun tidak memenuhi ketentuan ayat (1) berdasarkan pelepasan Hak Tanggungan atas sebagian obyek Hak Tanggungan oleh pemegang Hak Tanggungan yang dituangkan dalam akta otentik atau surat pernyataan di bawah tangan dengan mencantumkan secara jelas bagian dari obyek Hak Tanggungan yang dibebaskan dari beban Hak Tanggungan itu."

Ayat (4) "Pendaftaran hapusnya Hak Tanggungan atas sebagian dari obyek Hak Tanggungan yang tidak merupakan suatu hak atas tanah yang terdaftar tersendiri karena merupakan bagian dari hak atas tanah yang lebih besar

${ }^{25}$ Junaidi, H. (2010). Eksekusi Hak Tanggungan Secara Di Bawah Tangan Dengan Objek Hak Atas Tanah Milik Pihak Ketiga Pada PT. Bank Tabungan Negara (Persero) Cabang Tangerang. Doctoral dissertation, Universitas Diponegoro, Semarang. h.67.

${ }^{26}$ Harsono, Boedi. (2005).Hukum Agraria Indonesia Sejarah Pembentukan Undang-undang Pokok Agraria, Isi, dan Pelaksanaannya. Jakarta: Penerbit Djambatan.h.526 
dilakukan setelah dilakukan pemecahan atau pemisahan bidang tanah sebagaimana dimaksud dalam Pasal 133 dan 134."

Berdasarkan ketentuan tersebut diatas, dengan dilakukannya pemecahan ataupun pemisahan sebagian objek HT, beban HT atas objek tersebut masih tetap membebani keseluruhannya, meskipun mengakibatkan lahirnya bidang baru. Lahirnya bidang baru pada objek HT tidak mengakibatkan beban HT pada objek tersebut menjadi hapus dan sifat accesoir pada HT terus melekat pada obyek HTselama perjanjian pokoknya belum hapus.

\subsection{Perjanjian Pengalihan Obyek Hak Tanggungan}

Perjanjian jaminan HT adalah perjanjian yang bersifar accesoir, sehingga peralihan HT mengikuti peralihan perjanjian utang piutang sebagai perjanjian pokoknya. ${ }^{27}$ Berdasarkan Pasal 16 UUHT "Hak Tanggungan beralih karena cessie, subrogasi, pewarisan, atau sebab-sebab lain. Hak Tanggungan tersebut ikut beralih karena hukum kepada kreditor yang baru." Cessie adalah perbuatan hukum mengalihkan piutang oleh kreditur pemegang HT kepada pihak lain, sedangkan Subrogasi adalah penggantian kreditur oleh pihak ketiga yang melunasi utang debitur. Adapun sebabsebab lain adalah pengambilalihan atau penggabungan perusahaan sehingga menyebabkan beralihnya piutang perusahaan semula kepada perusahaan yang baru. ${ }^{28}$

Untuk mengalihkan objek HT, maka pertama kali diperlukan persetujuan tertulis dari pemegang HT, pengalihan objek HT tidak dapat dilakukan sebelum ada persetujuan tertulis tersebut. ${ }^{29}$ Selanjutnya barulah diperlukan perjanjian-perjanjian lainnya untuk mengalihkan sebagian obyek HT tersebut yaitu berupa perjanjian formil sebagai landasan hukumnya, dengan dibuatkan perjanjian berupa akta otentik. ${ }^{30}$ Berdasarkan Pasal 1868 KUHPerdata "Suatu akta otentik ialah suatu akta yang dibuat dalam bentuk yang ditentukan undang-undang oleh atau dihadapan pejabat umum yang berwenang untuk itu di tempat akta itu dibuat."

Notaris sebagai salah satu profesi hukum merupakan satu dari beberapa elemen dalam pelaksanaan hukum yang sebagian wewenangnya adalah menerbitkan suatu dokumen yang berupa akta dengan kekuatan sebagai akta otentik. Akta Otentik ialah akta yang dibuat dan diresmikan dalam bentuk menurut hukum, oleh atau dihadapan pejabat-pejabat umum, yang berwenang untuk berbuat demikian itu di tempat dimana akta itu dibuat. ${ }^{31}$

${ }^{27}$ Hutagalung, Arie. (2008). Praktek Pembebanan Dan Pelaksanaan Eksekusi Hak Tanggungan Di Indonesia. Jurnal Hukum dan Pembangunan, 3(2) 148-174.h.160

${ }^{28} \mathrm{Ibid}$.

29 Binsneyder Meike \& Abraham Ferry Rosando. (2020). Akibat Hukum Pengalihan Hak Tanggungan Tanpa Sepengetahuan Kreditur Dalam Tinjuan Asas Keseimbangan Dan Itikad Baik Dalam Putusan Pengadilan. Jurnal Hukum Bisnis Bonum Commune. 3(1) 104-119.h.108

30 Rahayu, E.(2014). Perlindungan Hukum Bagi Kreditor Pemegang Hak Tanggungan Atas Pemberian Kredit dengan Jaminan Hak Guna Bangunan terhadap Debitor yang Wanprestasi. Kumpulan Jurnal MahasiswanFakultas Hukum,1(1). h.6

${ }^{31}$ Harahap, M. Yahya. (2006).Pembahasan, Permasalahan dan Penerapan KUHAP. Jakarta: Sinar Grafika, h 76. 
Sifat otentik dari akta inilah merupakan unsur yang memenuhi keinginan terwujudnya kepastian hukum tersebut. Dalam Akta otentik itu sendiri mengandung pernyataan atas hak dan kewajiban seseorang atau individu (dalam bidang Perdata) dan oleh karena itu melindungi seseorang dalam kepentingan tersebut. Dengan memperhatikan ketentuan tersebut di atas, suatu akta pengalihan HT merupakan akta otentik apabila akta tersebut memenuhi kriteria: ${ }^{32}$

1. Dibuat dihadapan notaris.

Berdasarkan ketentuan Pasal 1 ayat (1) UUJN menentukan bahwa, "notaris adalah pejabat umum yang berwenang untuk membuat akta otentik. Lebih lanjut lagi, di dalam ayat (7) ditegaskan kembali bahwa "akta notaris adalah akta otentik yang dibuat oleh atau dihadapan notaris menurut bentuk dan tata cara yang ditetapkan dalamUUJN." Dengan demikian, suatu akta pengalihan HT yang dibuat dihadapan notaris adalah merupakan suatu akta ontentik.

2. Dibuat dalam bentuk yang ditentukan oleh Undang-undang.

Bentuk suatu akta notaris harus memenuhi aturan-aturan sebagaimana yang telah ditentukan oleh Undang-undang. Suatu akta terdiri dari Kepala Akta, Komparisi, Premisse Akta, Badan/Isi Akta, dan Akhir Akta.

Menurut Notaris Sri Handayani, Perjanjian formil tersebut yang digunakan adalah perjanjian pembebanan HT berupa SKMHT dan selanjutnya dibuatkan APHT, perjanjian tersebut dibuat setelah dilakukan roya atas objek HT. Adapun untuk mengalihkan sebagian objek HT, dibuatkan Perjanjian Pengikatan Jual Beli (PPJB) dan selanjutnya dibuatkan Akta Jual Beli (AJB) AJB untuk pengalihan sebagian objek HT tidak berbeda dengan AJB pada umumnya, hal ini dikarenakan objek HT sudah dilakukan roya sebelum diperjualbelikan. ${ }^{33}$

Adapun pendapat dari Notaris Wayan Sugitha, SH., untuk mengalihkan sebagian objek HT tidak perlu digunakan perjanjian formil dalam bentuk SKMHT dan APHT guna memberikan jaminan kepada pemegang HT/kreditur, namun dapat digunakan Perjanjian Penanggungan atau Borghtoch untuk menjamin pemegang HT/kreditur. ${ }^{34}$ Berdasarkan Pasal 1820 KUHPer "perjanjian penanggungan adalah suatu perjanjian dengan mana seorang pihak ketiga, guna kepentingan si berpiutang, mengikatkan diri untuk memenuhi perikatannya si berutang, manakala orang ini sendiri tidak memenuhinya." Dibuatnya Perjanjian Penanggungan ini bertujuan untuk memberikan jaminan kepada pemegang HT/kreditur terkait pelunasan hutang pemberi HT/debitur setelah seluruh hak tanggungan terhadap tanah dilakukan roya.

Perjanjian Borghtoch, tidak termasuk ke dalam perjanjian formil karena dapat dibuat dibawah tangan dan sifatnya bebas tanpa harus dibuatkan dalam bentuk akta autentik, namun dalam hal ini harus diperjanjikan terkait besaran hutang dan waktu berakhirnya perjanjian. Adapun alternatif lain untuk melakukan pengalihan sebagian

${ }^{32}$ Andiyaningsih, Dessy \& Umar Ma'ruf. (2018). Pengalihak Hak Tanggungan Pada Perbankan Di Kabupaten Banjarnegara. Jurnal Akta. 5(1), 87-96, h.92.

33 Hasil wawancara dengan Notaris Sri Andayani SH., Notaris/PPAT Denpasar pada tanggal tanggal 9 Oktober 2020.

34 Hasil wawancara Notaris I Wayan Sugitha, SH., Notaris/PPAT Denpasar dari hasil wawancara pada tanggal 10 Oktober 2020 
objek HT dapat dilakukan dengan membuat beberapa perjanjian, antara lain terdiri dari:

1. Perjanjian konsensual dan Perjanjian Tidak Bernama

a. Dibuatkan perjanjian mengenai pembayaran angsuran kredit dengan cara membuat kesepakatan untuk menjual sebagain objek HT antara pemegang HT/Kreditur dengan pemberi HT/debitur.

b. Membuatkan perjanjian terkait pembayaran hasil penjualan objek HT yang langsung dibayaran ke rekening pemegang HT/kreditur.

c. Membuat perjanjian antara pemegang HT/kreditur dengan pembeli dan pemberi HT/debitur, yang isinya menunjuk PPAT tertentu terkait pengalihan objek HT.

d. Membuatkan perjanjian mengenai pemecahan dan pemisahan objek HT yang dibuat pada saat dilakukan jual beli.

e. Membuat perjanjian antara pembeli dengan pemberi HT/debitur terkait proses jual beli pada PPAT tertentu.

f. Membuat perjanjian mengenai pengurusan sertifikat sampai terbitnya sertifikat.

2. Perjanjian Formil dan Bernama

a. Membuat perjanjian antara Pemberi HT/debitur dengan Pembeli untuk melakukan Pengikatan Jual Beli (PJB). Perjanjian ini harus atas sepengetahuan dan persetujuan pemegang HT/kreditur. PJB ini dilakukan sebelum dilakukan roya dan pemisahan atas objek HT. Tujuannya untuk memperoleh kepastian bahwa ada pembeli setelah dilakukan roya. Selanjutnya dibuatkan Akta Jual Beli (AJB). Akta ini dibuat setelah tanah bidang baru muncul dan hapus beban HT-nya. AJB ini memindahkan hak atas tanah kepada pembeli.

b. Membuat Surat Kuasa Memberikan Hak Tanggungan (SKMHT) dan selanjutnya dibuatkan Akta Pemberian Hak Tanggungan (APHT).

\section{Kesimpulan}

Hasil penelitian ini menyimpulkan bahwa: pertama, sebagian obyek HT dapat dilakukan pengalihan, meskipun tidak ada janji dalam APHT sebelumnya, hal ini didasarkan pada ketentuan Pasal 2 ayat (2) UUHT dan sifat Hak Tanggungan yaitu droit de suite, yang diatur pada Pasal 7 UUHT. Kedua, untuk mengalihkan objek HT perlu dibuat perjanjian, yaitu 1) Perjanjian mengenai kesepakatan menjual sebagian obyek HT dengan tujuan membayar angsuran kredit; 2) perjanjian mengenai kesepakatan agar pembeli melakukan pembayaran langsung ke rekening pemegang HT/kreditur; 3) Perjanjian mengenai pemecahan dan pemisahan objek HT dan perjanjian mengenai pengurusan sertifikat sampai terbitnya; 4)Perjanjian antara Pemberi HT dan pembeli untuk dibuatkan PJB dan AJB.

\section{DAFTAR PUSTAKA}

\section{BUKU:}

Harsono, Boedi. (2005). Hukum Agraria Indonesia Sejarah Pembentukan Undang-undang Pokok Agraria, Isi, dan Pelaksanaannya. Penerbit Djambatan. Jakarta. 
Imaniyanti, Neni Sri. (2010). Pengantar Hukum Perbankan Indonesia. PT. Refika Aditama. Bandung

Muljadi, Kartini \& Gunawan Widjaja. (2005) Seri Hukum Harta Kekayaan: Hak Tanggungan. Prenada Media Group. Jakarta.

Perangin, Effendi. (1995) Praktek Penggunaan Tanah sebagai Jaminan Kredit. PT Raja Grafindo Persada. Jakarta.

Salim HS. (2004). Perkembangan Hukum Jaminan di Indonesia, PT Raja Grafindo Persada. Jakarta.

Usman, Rahmadi. (2001) Aspek-aspek Hukum Perbankan di Indonesia. PT Gramedia Pustaka Utama. Jakarta.

\section{JURNAL:}

Andiyaningsih, Dessy \& Umar Ma'ruf. (2018). Pengalihak Hak Tanggungan Pada Perbankan Di Kabupaten Banjarnegara. Jurnal Akta. 5(1), 87-96.

Binsneyder Meike \& Abraham Ferry Rosando. (2020). Akibat Hukum Pengalihan Hak Tanggungan Tanpa Sepengetahuan Kreditur Dalam Tinjuan Asas Keseimbangan Dan Itikad Baik Dalam Putusan Pengadilan. Jurnal Hukum Bisnis Bonum Commune. 3(1) 104-119

Dewi, A. (2019). Peningkatan Hak Guna Bangunan Rumah Tinggal Yang Dibebani Hak Tanggungan Menjadi Hak Milik Diatas Hak Pengelolaan. JCH (Jurnal Cendekia Hukum), 5(1), 18-31.

Djatmiko, A. A. (2017). Aktualisasi Prinsip 5C Pada Pelaksanaan Perjanjian Kredit Dengan Jaminan Hak Atas Tanah Belum Bersertifikat.Jurnal Yustitiabelen, 3(1), 129-157.

Doly, D. (2016). Aspek Hukum Hak Tanggungan Dalam Pelaksanaan Roya. Negara Hukum: Membangun Hukum untuk Keadilan dan Kesejahteraan, 2(1), 103-128.

Haryati, S. (2009). Pertumbuhan kredit perbankan di Indonesia: Intermediasi danpengaruh variabel makro ekonomi. Jurnal Keuangan dan Perbankan, 13(2), 299-310.

Hutagalung, Arie. (2008). Praktek Pembebanan Dan Pelaksanaan Eksekusi Hak Tanggungan Di Indonesia. Jurnal Hukum dan Pembangunan, 3(2) 148-174

Junaidi, H. (2010). Eksekusi Hak Tanggungan Secara Di Bawah Tangan Dengan Objek Hak Atas Tanah Milik Pihak Ketiga Pada PT. Bank Tabungan Negara (Persero) Cabang Tangerang. Doctoral dissertation, Universitas Diponegoro, Semarang.

Rahayu, E. (2014). Perlindungan Hukum Bagi Kreditor Pemegang Hak Tanggungan Atas Pemberian Kredit dengan Jaminan Hak Guna Bangunan terhadap Debitor yang Wanprestasi. Kumpulan Jurnal Mahasiswa Fakultas Hukum, 1(1). 
Sari, A. A. I. W., Atmadja, I. B. P., \& Darmadi, A. A. S. W. (2015). Pelaksanaan Perjanjian Kredit Jaminan Perorangan Terkait Debitur Wanprestasi Pada Bank Perkreditan Rakyat. Kertha Semaya: Journal Ilmu Hukum, 1-15.

Siswanto, C. T. (2016). Pembebanan Hak Tanggungan Yang Didahului Surat Kuasa Membebankan Hak Tanggungan (SKMHT) Di Kantor Pertanahan Kabupaten. Kota Di Wilayah Daerah Istimewa Yogyakarta.. Jurnal Cakrawala Hukum, 12(1).

Sunanda, B., Wahab, A. A., \& Abubakar, M. (2013). Pembatalan Perjanjian Jual Beli Tanah Meskipun Telah Memiliki Akta Jual Beli Tanah Dari PPAT OLeh Pengadilan Negeri. Jurnal Ilmu Hukum ISSN, 2302, 0180.

Utami, P.D.Y. (2019). Kajian Yuridis Agunan Yang Diambil Alih (AYDA) Oleh Bank. Kerta Dyatmika, 16(2), 69-77.

Utami, P. D. Y., Diantha, I. M. P., \& Sarjana, I. M. (2018). Kedudukan Hukum Grosse Akta Pengakuan Hutang Notariil dalam Pemberian Kredit Perbankan. Acta Comitas: Jurnal Hukum Kenotariatan, 3(1), 201-214.

Widayati, R., \& Herman, U. (2019). Penyelesaian Kredit Bermasalah Pada PT. Bank Perkreditan Rakyat (BPR) Nagari Kasang.

Wiguna, M. O. C. (2018). Surat Kuasa Membebankan Hak Tanggungan Dan Pengaruhnya Terhadap Pemenuhan Asas Publisitas Dalam Proses Pemberian Hak Tanggungan. Jurnal Legislasi Indonesia, 14(4), 439-446.

\section{PERATURAN PERUNDANG-UNDANGAN}

Kitab Undang-Undang Hukum Perdata

Undang-Undang Nomor 4 Tahun 1996 tentang Hak Tanggungan atas Tanah beserta Benda-Benda yang Berkaitan dengan Tanah, Lembaran Negara Republik Indonesia Tahun 1996 Nomor 42, Tambahan Lembaran Negara Republik Indonesia Nomor 3632.

Peraturan Pemerintah Republik Indonesia Nomor 24 Tahun 1997 tentang Pendaftaran Tanah

Peraturan Menteri Agraria/ Kepala Badan Pertanahan Nasional Republik Indonesia No.3 Th.1997 tentang Ketentuan Pelaksanaan Peraturan Pemerintah Nomor 24 Tahun 1997 